\title{
Possible Influence of Oxidative Stress on Development of Raynaud Phenomenon in Patients With CREST Scleroderma Syndrome
}

\author{
Hristina KOCIĆ ${ }^{1,2}$, Bojana STAMENKOVIĆ ${ }^{3}$, Danijela POPOVIĆ ${ }^{2}$, Zorana ZLATANOVIĆ2 \\ Tomislav MARKOVIĆ ${ }^{3}$, Danica TIODOROVIĆ 4 \\ ${ }^{1}$ Medical Faculty University of Maribor, Slovenia \\ ${ }^{2}$ Clinic of Dermatology, Clinical Centrer Niš, Serbia \\ ${ }^{3}$ Institute for Prevention, Treatment and Rehabilitation Niška Banja, Faculty of Medicine, University of Niš, Serbia \\ ${ }^{4}$ Clinic of Dermatology, Faculty of Medicine, University of Niš, Serbia \\ *Correspondence: Hristina Kocić, E-mail: hristinakyu@yahoo.com
}

UDC 616.5-004:577.125

\begin{abstract}
CREST syndrome represents a form of scleroderma where the progressive autoimmune reaction is mainly manifested by the main symptoms, which make this acronym: calcinosis cutis, Raynaud phenomenon, esophageal dysmotility, sclerodactyly and teleangiectasia. Among the first affected organs is the skin followed by the excessive fibrosis manifested by the deposition of collagen in dermis. Reactive oxygen species (ROS) theory has been underlined as one of the main pathogenetic mechanisms and triggering factor in development of scleroderma. The present study was aimed at estimating the marker of lipid peroxidation products (MDA) in plasma of patients with CREST syndrome having manifested symptoms of both Raynaud syndrome and positive ANA antibodies. The lipid peroxidation (MDA) level was significantly higher in the patients who had CREST syndrome and Raynaud syndrome for less than 10 years compared to the patients suffering from Raynoud syndrome for more than 10 years $(p<0.05)$. Both groups were found to have a significant MDA level increase $(p<0.001)$ compared to the control healthy subjects. In conclusion, the relationship between lipid peroxidation (MDA level) and Raynaud syndrome appearance may emphasize the role of ROS produced by the ischemia-reperfusion injury as an early pathogenetic mechanism in CREST scleroderma syndrome.
\end{abstract}

Key words: CREST Syndrome; Scleroderma, Systemic; Raynaud Disease; Reactive Oxygen Species; Oxidative Stress; Lipid Peroxidation; Malondialdehyde

\section{Introduction}

Scleroderma represents a progressive autoimmune disease, where cutaneous and visceral fibrosis, together with vascular damage, lead to premature mortality. CREST syndrome represents a form of scleroderma where the autoimmune reaction is manifested by the main symptoms, which make this acronym: calcinosis cutis, Raynaud phenomenon, esophageal dysmotility, sclerodactyly and teleangiectasia. Among the first affected organs is skin and the excessive fibrosisis manifested by the deposition of collagen, followed by the infiltration of mononuclear cells in dermis (1-3). Increased thickening of small blood vessels is accompanied with the above mentioned symptoms. The pathological hallmark is the overproduction of the extracellular matrix (ECM). The main cells responsible for the excessive ECM synthesis are fibroblasts, myofibroblasts and perycites, stimulated mainly by transforming the growth factor-beta (TGF- $\beta$ ). Exctracellular matrix (ECM) proteins accumulated in dermis are the types I, III, IV, and VII of collagen and fibronectin. The extracellular glycosaminoglycans and proteoglycans are also found in ECM and in the intima of blood vessels $(4,5)$.

Reactive oxygen species (ROS) theory has been underlined as one of the main pathogenetic mechanisms and triggering factor in the development of connective tissue 
diseases. The free oxygen radicals are liberated by activated inflammatory cells and may be results of ischemia reperfusion tissue damage. The association between oxidative stress and accelerated fibrosis may be a result of their interrelationship, where free oxygen radicals may stimulate fibroblasts migration, fibrous tissue synthesis and accumulation, while active fibroblasts may result in free oxygen radicals liberation $(6,7)$.

Lipid peroxidation represents a ROS action on unsaturated fatty acids, the main elements of phospholipids. Lipid peroxidation is finished by terminal reaction a production of malondyaldehyde (MDA). The polyunsaturated fatty acids of cell membranes and blood lipoproteins are particularly affected. Damaged cell membranes undergo a modification of their structure (altered fluidity), followed by the increased permeability and altered receptor function $(8,9)$.

Raynaud's phenomenon is a prominent symptom of CREST syndrome. It is a consequence of endothelial damage, followed by ischemia-reperfusion injury, vasospasm and the intimal proliferation (10). Dysfunction of blood vessels flow is accompanied with the procoagulant state, and because of the elevation of factor VIII-von Willebrand and thrombocytosis was documented. The observed changes are adrenergic and endothelin-dependent. Taken together, vasospasm, hypoxia and oxidative stress induce the ischemiareperfusion injury. A pro-coagulant state and the impairment of endothelium-dependent relaxation are the main pathogenetic hall- marks due to the decreased bioavailability of nitric oxide-NO (11-13). The decreased NO bioavailability is the result of toxic peroxinitrite (ONOO) production, due to the excess of both $\mathrm{NO}$ and ROS and their rapid reaction (14).

The present study was aimed at estimating the marker of lipid peroxidation products (MDA) in plasma of patients with CREST syndrome having manifested symptoms of Raynaud syndome and anti-nuclear antibodies (ANA).

\section{Patients and Methods}

The study included 15 female patients with CREST syndrome, having the symptoms of Raynaud syndome for less than 10 years (4 patients) and more than 10 years (11 patients). Age-matched female healthy subjects (20) were used as control. The patients with CREST syndrome were diagnosed by the clinical and laboratory assessment according to the working classification of scleroderma (15). All patients were positive for ANA immune test. Raynaud phenomenon was documented by the recurrent spasms of small vessels, followed by the pallor, cyanosis and the reactive hyperemia in fingers and toes, triggered by cold or the emotional stress.

\section{Results}

Demographic characteristics of female patients are given in Table 1, which shows the duration of the disease and the appearance of Raynaud phenomenon. All patients were ANA

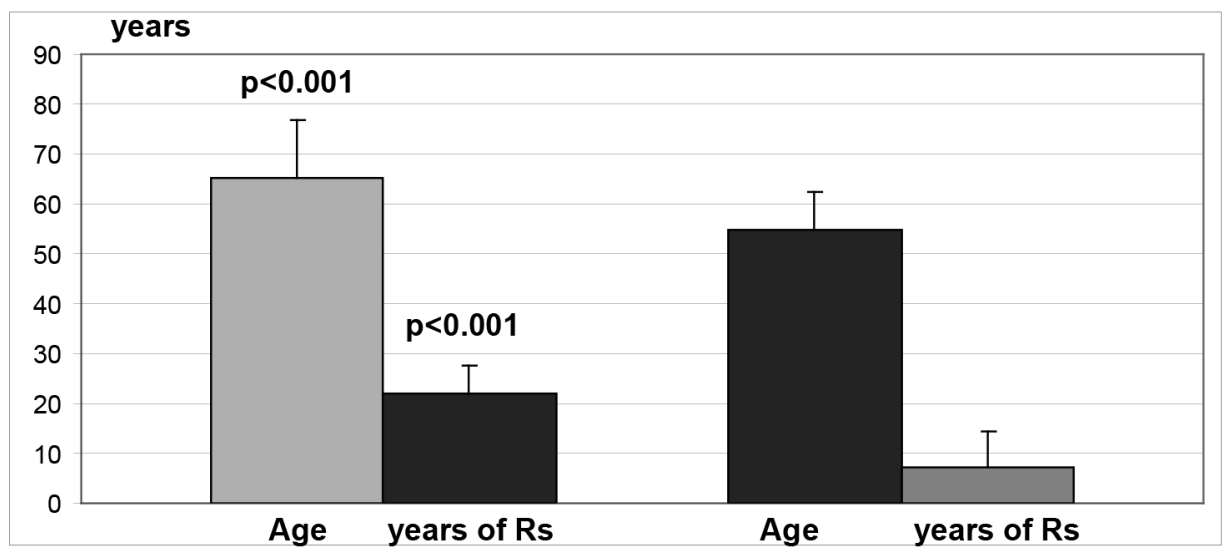

Figure 1. Age of patients and years of Raynaud syndrome duration in examined groups of patients with CREST syndrome 


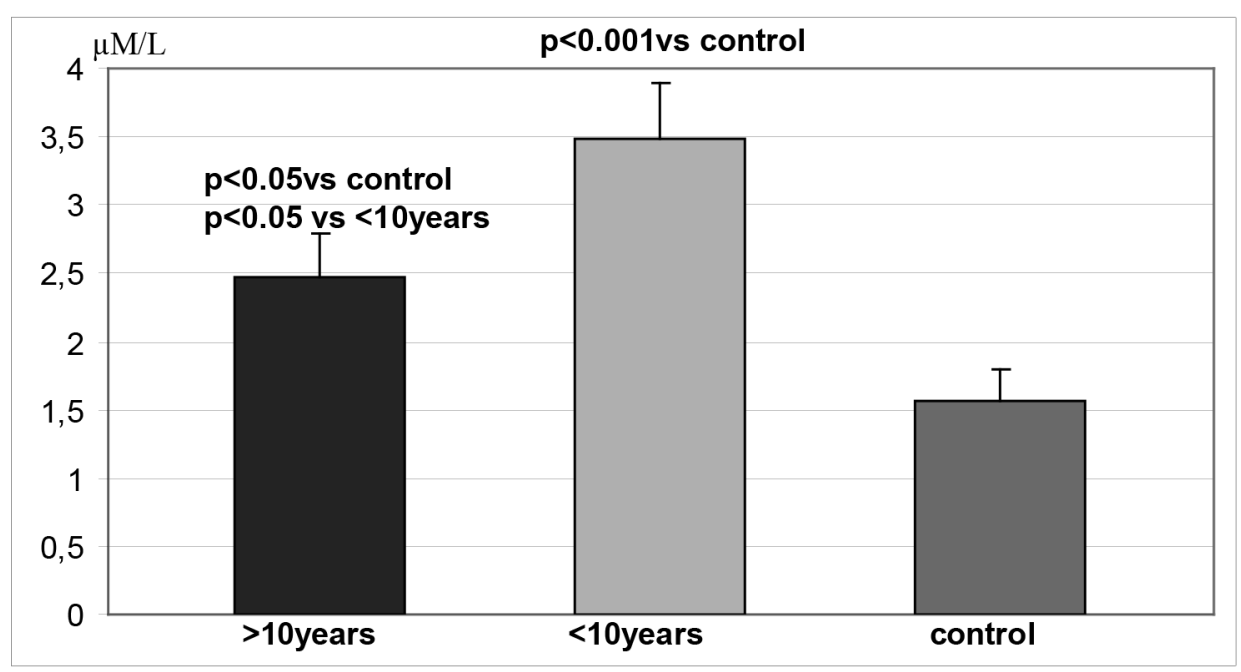

Figure 2. Lipid peroxidation (MDA) level in the examined groups of patients with CREST syndrome and the controls

positive. The level of MDA $(\mu \mathrm{M} / \mathrm{L})$ was almost two times higher in the patients suffering from scleroderma for less than 10 years than in the patients suffering from it for more than 10 years and in the control healthy subjects.

\section{Discussion}

In order to emphasize the importance of ROS in scleroderma development, some theories have been proposed regarding the increased ROS liberation (16). The main ROS are superoxide anion radical $\left(\mathrm{O}^{--}\right)$, hydrogen peroxide $\left(\mathrm{H}_{2} \mathrm{O}_{2}\right)$, hydroxyl radical $\left(\mathrm{OH}^{*}\right)$ and peroxynitrite $\left(\mathrm{ONOO}^{-}\right)$(17). ROS mechanism in the development of this disease seems to be the first triggering mechanism since the increased MDA level has been reported in the patients suffering from scleroderma for less than 10 years (Figure 1). In the period of limited blood flow intracellular protease activation is induced by prolonged ischemia, which may lead to interconversion of xanthine dehydrogenase to its ROS-producing form xanthine oxidase. Ischemia may induce a cell energy crisis followed by the accelerated degradation of ATP. Upon reperfusion with oxygen supply the last reaction catalyzed by xanthine oxidase is followed by the simultaneous liberation of uric acid and free radicals (superoxide anion radical and hydrogen peroxide) (18). Ischemia can also induce nitric oxide liberation (NO), which can react with superoxide anion radical, when the peroxinitre
(ONOO) radical is formed, one of the ugliest ROS. In this way, the main pathogenetic mechanism of ROS liberation in CREST syndrome is the ischemia-reperfusion injury. The other mechanism of ROS liberation belongs to mitochondrial injury, where liberated superoxide anion radical in the mitochondrial respiratory chain can alter mitochondrial membrane permeability (19). Moreover, a very important enzymatic complex responsible for additional ROS production would be also NADPH oxidase (NOX) produced by phagocytic cells. The additional mechanism is the imbalance between pro and antioxidative defense with the decreased activity of the antioxidative defense enzymes, especially of catalase and superoxide dismutase (SOD) $(13,14,20,21)$. Increased oxidative stress can stimulate fibroblasts to produce ECM (accelerated fibrogenesis) and to secrete inflammatory cytokines. Liberated ROS can directly damage biomollecules, lipids, proteins and nucleic acids. Oxidativelly-modified unsaturated fatty acids derived from phospholipids proceed through the well-defined steps finally producing terminal product malondyaldehyde (MDA). The first step is the reaction of ROS with fatty acids and unstable fattyacid radical production, peroxyl-fatty acid radical production and lipid peroxide. The process proceeds continually as a "chain reaction mechanism". Membrane injury may cause cell apoptosis with subsequent tissue and organ injury $(8,9)$. 


\section{Conclusion}

In conclusion, the inverse relationship of oxidative damage (MDA level) and disease appearance may reflect the role of ROS as an early pathogenetic mechanism of disease development and consequent ischemia-reperfusion injury in CREST scleroderma syndrome.

\section{Abbreviations}

ROS - reactive oxygen species

MDA - malondyaldehyde

TGF- $\beta$ - transforming growth factor beta

ECM - extracellular matrix

$\mathrm{NO}$ - nitric oxide

ONOO peroxynitrite

NOx - NADPH oxidase (NOX)

SOD - superoxide dismutase

\section{References}

1. Velayos EE, Masi AT, Stevens MB, Shulman LE. The 'CREST' syndrome. Comparison with systemic sclerosis (scleroderma). Arch Intern Med. 1979;139(11):1240-4.

2. Merlino G, Germano S, Carlucci S. Surgical management of digital calcinosis in CREST syndrome. Aesthetic Plast Surg. 2013;37(6):1214-9.

3. Cutler TS, Reyentovich A. Peripheral phenomena in a woman with calcinosis, Raynaud phenomenon, esophageal dysmotility, sclerodactyly, and telangiectasia (CREST) syndrome-associated pulmonary hypertension. Circulation. 2012;125(9):e413-4.

4. Shenavandeh S. Calcinosis universalis in a patient with overlap of scleroderma/dermatomyositis. J Clin Rheumatol. 2012;18(1):57.

5. Duzgun N. Cutaneous calcinosis in a patient with limited scleroderma: CREST Syndrome. Eur J Rheumatol. 2017;4(4):305-6.

6. Gabrielli A, Avvedimento EV, Krieg T. Scleroderma. N Engl J Med. 2009;360(19):1989-2003.

7. Simonini G, Cerinic MM, Generini S, Zoppi M, Anichini $\mathrm{M}$, Cesaretti $\mathrm{C}$, et al. Oxidative stress in systemic sclerosis. Mol Cell Biochem. 1999;196(1-2):85-91.

8. Mylonas C, Kouretas D. Lipid peroxidation and tissue damage. In Vivo. 1999;13(3):295-309.
9. Ayala A, Munoz MF, Arguelles S. Lipid peroxidation: production, metabolism, and signaling mechanisms of malondialdehyde and 4-hydroxy-2-nonenal. Oxid Med Cell Longev. 2014;2014:360438.

10. Herrick AL. Pathogenesis of Raynaud's phenomenon. Rheumatology (Oxford). 2005;44(5):587-96.

11. Balbir-Gurman A, Braun-Moscovici Y, Livshitz V, Schapira D, Markovits D, Rozin A, et al. Antioxidant status after iloprost treatment in patients with Raynaud's phenomenon secondary to systemic sclerosis. Clin Rheumatol. 2007; 26(9):1517-21.

12. Johnson JM, Yen TC, Zhao K, Kosiba WA. Sympathetic, sensory, and nonneuronal contributions to the cutaneous vasoconstrictor response to local cooling. Am J Physiol Heart Circ Physiol. 2005;288(4):H1573-9.

13. Yamazaki F, Sone R, Zhao K, Alvarez GE, Kosiba WA, Johnson JM. Rate dependency and role of nitric oxide in the vascular response to direct cooling in human skin. J Appl Physiol. 2006;100(1):42-50.

14. Matucci Cerinic M, Kahaleh MB. Beauty and the beast. The nitric oxide paradox in systemic sclerosis. Rheumatology. 2002;41(8):843-7.

15. Maricq HR, Valter I. A working classification of scleroderma spectrum disorders: a proposal and the results of testing on a sample of patients. Clin Exp Rheumatol. 2004;22(3 Suppl 33):S5-13.

16. Murrel DF. A radical proposal for the pathogenesis of scleroderma. J Am Acad Dermatol. 1993;28(1):78-85.

17. Valko M, Leibfritz D, Moncol J, Cronin MT, Mazur M, Telser J. Free radicals and antioxidants in normal physiological functions and human diseases. Int $\mathrm{J}$ Biochem Cell Biol. 2007;39(1):44-84.

18. Granger DN. Role of xanthine oxidase and granulocytes in ischemia-reperfusion injury. Am J Physiol. 1988;255(6 Pt 2):H1269-75.

19. Gabrielli A, Svegliati S, Moroncini G, Amico D. New insights into the role of oxidative stress in scleroderma fibrosis. Open Rheum J. 2012;6(Suppl 1: M4):87-95.

20. Bedard K, Krause KH. The nox family of ROS-generating NADPH oxidases: physiology and pathophysiology. Physiol Rev. 2007;87(1):245-313.

21. Sambo P, Baroni SS, Luchetti M, Paroncini P, Dusi S, Orlandini $G$, et al. Oxidative stress in scleroderma: maintenance of scleroderma fibroblast phenotype by the constitutive up-regulation of reactive oxygen species generation through the NADPH oxidase complex pathway. Arthritis Rheum. 2001;44(11):2653-64.

\section{Mogući uticaj oksidativnog stresa na razvoj Rejnoovog fenomena kod pacijenata sa CREST Skleroderma sindromom}

\section{Sažetak}

CREST sindrom predstavlja jedan oblik skleroderme gde se progresivna autoimuna reakcija uglavnom manifestuje osnovnim simptomima koji čine akronim a to su calci- nosis cutis, Rejnoov fenomen, ezofagealni dismotilitet, sklerodaktili i teleangiektazija. Među najugroženijim organima je koža, zatim prekomerna fibroza koja se mani- 
festuje taloženjem kolagena u dermisu. Teorija o reaktivnim vrstama kiseonika (ROS - reactive oxygen species) navodi se kao jedan od osnovnih patogenih mehanizama i faktor okidač u nastanku skleroderme. Cilj ovog rada je procena markera produkata lipidne peroksidacije (MDA) u plazmi pacijenata sa CREST sindromom koji su ispoIjili i simptome Rejnoovog sindroma i pozitivna ANA antitela. Nivo lipidne peroksidacije (MDA) bio je značajno viši kod pacijenata koji su imali CREST sindrom i Rejno- ov sindrom manje od 10 godina nego kod pacijenata koji su patili od Rejnoovog sindroma duže od 10 godina ( $p$ $<0,05)$. U obe grupe pacijenata zabeležen je značajan porast MDA nivoa ( $p<0,001)$ u poređenju sa zdravom kontrolnom grupom. Odnos između lipidne peroksidacije (MDA nivo) i pojave Rejnoovog sindroma može da naglasi ulogu reaktivnih vrsta kiseonika (ROS) koje stvori ishemijska reperfuziona povreda kao rani patogeni mehanizam CREST skleroderma sindroma.

Ključne reči: KREST sindrom; Sistemska skleroderma; Rejnaudova bolest; Reaktivne vrste kiseonika; Oksidativni stres; Lipidna peroksidacija; Malondialdehid 